"SMEs: do they follow a shotgun or rifle approach when it comes to target marketing?"

\begin{tabular}{ll} 
AUTHORS & $\begin{array}{l}\text { Michael C. Cant } \\
\text { Johannes A. Wiid } \\
\text { Adri Meyer }\end{array}$ \\
& $\begin{array}{l}\text { Michael C. Cant, Johannes A. Wiid and Adri Meyer (2016). SMEs: do they follow } \\
\text { a shotgun or rifle approach when it comes to target marketing?. Problems and } \\
\text { Perspectives in Management, 14(3-2), 504-511. doi:10.21511/ppm.14(3- } \\
\text { 2).2016.06 }\end{array}$ \\
\hline DRTICLE INFO & http://dx.doi.org/10.21511/ppm.14(3-2).2016.06 \\
\hline RELEASED ON & Tuesday, 27 September 2016 \\
\hline JOURNAL & "Problems and Perspectives in Management" \\
\hline FOUNDER & LLC "Consulting Publishing Company "Business Perspectives"
\end{tabular}

NUMBER OF REFERENCES

0

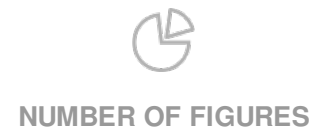

0

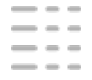

NUMBER OF TABLES

0

(C) The author(s) 2023. This publication is an open access article. 
Michael C. Cant (South Africa), Johannes A. Wiid (South Africa), Adri Meyer (South Africa)

\title{
SMEs: do they follow a shotgun or rifle approach when it comes to target marketing?
}

\begin{abstract}
As SMEs are the drivers of employment and GDP in many cases, SMEs are also critical to the development of any economy and their survival and success are, thus, important. With the high levels of failure of SMEs, it has become imperative that there is a drive to ensure the survival of SMEs. A way in which SMEs, can enhance their potential success rate and business performance is by means of proper target market selection in order for the business to focus their marketing efforts. This will allow the business to timeously identify opportunities and threats in the market and to react to these situations. The business will also have a greater understanding of their target market, and their needs and wants. Understanding the target market will assist the business in developing marketing strategies that are suited for the target market and enhance its chances of success. This study aimed to identify whether SME owners and managers have target market knowledge within a South African SME context. The main results indicate that although SME owners and managers claim they are aware of their specific target markets (90\%), they do not have customer knowledge regarding the psychographic and demographic aspects of their target market. By using effective target marketing communication, SMEs can improve on their merchandising planning and product assortment and offerings to better serve their target market(s).
\end{abstract}

Keywords: target marketing, SMEs, South Africa.

JEL Classification: M310, L26.

\section{Introduction}

Small to medium size enterprises (SMEs) are considered the backbone of any economy, as they drive sustainable growth and are major contributors to employment in any economy (Caan, 2013, p. 57; Chimucheka, 2013, p. 784). The United Kingdom is estimated to have 7.9 million SMEs which employ 24.3 million people (Caan, 2013). In the European Union, SMEs contribute to $99 \%$ of SMEs (estimated at 25 million SMEs) which provide up to 75 million jobs (European Commission, 2005, p. 5). In developing countries such as Nigeria, more than $90 \%$ of enterprises are SMEs which contribute $10 \%$ to the country's Gross Domestic Product (GDP) (Ghandi \& Amissah, 2014, p. 329). As can be seen from the above figures, SMEs contribute positively to a country's economic growth, poverty alleviation, social stability and job creation.

The contribution of SMEs in South Africa is no different and increases the prosperity in rural areas and enhances the population's general level of economic participation (Chimucheka, 2013, p. 784). Abor and Quartey (2010, p. 218) estimated that 91\% of formal business entities in South Africa consist of SMEs. Research also suggests that SMEs contribute between $52 \%$ and $57 \%$ to the GDP of South Africa

(C) Michael C. Cant, Johannes A. Wiid, Adri Meyer, 2016.

Michael C. Cant, D.Com. Marketing Management, Research \& Development Professor, Department of Marketing and Retail Management, University of South Africa, South Africa.

Johannes A. Wiid, D.Com. Marketing Management, Research \& Development Professor, Department of Marketing and Retail Management, University of South Africa, South Africa.

Adri Meyer, M.Com. Marketing Management, Lecturer, Department of Marketing and Retail Management, University of South Africa, South Africa. and $61 \%$ to the creation of jobs within the country (Notcutt \& Habberton, 2013). This is confirmed already in 2008 by Modimogale (2008, p. 7) stating that SMEs contribute greatly towards the growth of the GDP and the reduction of unemployment in the South African economy.

The growth rate of SMEs in South Africa is, however, low and, on average, $50 \%$ of SMEs fail to grow (Ladzani \& Mbonyane, 2011, p. 550). Previous research conducted on SMEs in a South African context has found that the major reasons why SMEs fail are due to a lack of marketing activities and skills (Cant, 2012, p. 1109; Krake, 2005, p. 228; Tang, Wang \& Zhang, 2007, p. 119; Van Scheers, 2011, p. 5050). The lack of marketing skills includes not understanding the market, incorrect market analysis, lack of education and training, lack of competitiveness, lack of marketing of products and services and lack of target marketing and segmentation (Van Scheers, 2011, p. 5050).

With the survival and failure of SMEs being topical in research worldwide due to developmental roles such as job creation and poverty alleviation (Hove \& Mashocha, 2014, p. 254; Van Scheers, 2011, p. 5056), research of whether SME owners and managers have the necessary knowledge regarding their target market and consumers warrants a detailed investigation.

The remainder of the article consists of a brief background of SMEs and the literature gap in academia, followed by a literature review which will discuss customer knowledge, segmentation and target marketing. The aim of the study is, then, presented, followed by the methodology, results, discussion, conclusion and recommendations. 


\section{Background}

There are many factors that make SMEs different, including turnover, industry, number of employees, format of the business, financial practices, decision making processes and trading styles (Modimogale, 2008, p. 17; Carvalho, 2007, p. 19). The definition of SMEs varies in different countries and is usually based on the economy, government policies and regulations of the country (Etuk, Etuk \& Baghebo, 2014, p. 656). Small businesses in developed countries such as the United States of America and the United Kingdom may be considered large scale businesses in a developing country (Van Scheers, 2011, p. 5048). In South Africa, SMEs are defined by the National Small Business Act 102 of 1996 as " $a$ business enterprise that employs no more than 100 employees" (Abor \& Quartey, 2010, p. 222). They further define SMEs as "a separate and distinct entity including cooperative enterprises and nongovernmental organizations managed by one owner or more, including its branches or subsidiaries if any is predominantly carried out in any sector or subsector of the economy mentioned in the schedule of size standards and can be classified as a SME by satisfying the criteria mentioned in the schedule of size standards" (Government Gazette of the Republic of South Africa, 2003).

Independent of the firm size, turnover, decision making processes and trading styles, it is necessary for organizations to investigate their macro and micro environmental obstacles. Previous research regarding the obstacles that South African SMEs are faced with identified various macro and micro environmental challenges these businesses need to cope with. The macro environmental obstacles that SMEs are battling with included lack of access to finance, high interest rates, high inflation rates, unemployment, lack of support from government, government legislation and crime (Brink, Cant \& Ligthelm, 2003, p. 1; Cant \& Wiid, 2013, p. 713; Olawale \& Garwe, 2010, p. 734).

The micro environmental obstacles, on the other hand, included the incorrect location of businesses, lack of a marketing plan, lack of marketing research, lack of training and skills, misreading customer trends, implementing the incorrect pricing strategies, low demand for their products, lack of target segmentation and lack of target market knowledge by SMEs (Brink, Cant \& Ligthelm, 2003, p. 1; Cant \& Wiid, 2013, p. 713; Mpofu \& Chingwede, 2013, p. 90; Van Scheers, 2011, p. 5050). A common problem in SME development is that SME owners and managers usually pay more attention to financial and production issues (Bresciani \& Eppler, 2010, p. 365) and, consequently, the importance of marketing, and particularly target marketing, is overlooked.
Limited research exists on whether SME owners and managers have specific target market knowledge, particularly in a South African context. As a result, this article contributes to the body of knowledge regarding target market research in an SME environment by contributing significant results to the field.

\section{Literature review}

2.1. Customer knowledge. Organizations have become increasingly aware of the importance and strategic asset of customer knowledge. Customer knowledge refers to the understanding of your customers, their needs, wants and aims. It also refers to a strategic initiative employed by companies to acquire intelligence from their customers, as it relates to their organization (Business Dictionary, 2016). The aim of building up a strong body of customer knowledge is to develop and manage customer relationships currently and long-term and to create value to customers. Customer knowledge should include perspectives on key customers and trend information across the broad customer base which allows individuals to be targeted for communication and research, and growing relationships (Anon, 2016).

The knowledge from customers enables the organization to aim at the right target market segments. Mohammadhossein, Zakaria, Rafsanjani and Asadi (2013, p. 615) further explain that customer knowledge management and customer segmentation will assist to categorize information of the customer's knowledge to improve the efficiency of customizing information based on diverse categories. As a result, this information allows an organization to provide higher service probability and to improve customer satisfaction.

\subsection{Segmentation and target marketing.} Segmentation and target marketing is of vital importance to businesses. To achieve maximum customer satisfaction, marketers need to divide the heterogeneous markets into fairly homogeneous subsets of customers which is called market segmentation. It is, then, assumed that each market segment consists of customers with similar characteristics, needs and wants. The bases according to which consumer markets can be segmented include demographic variables, psychographic variables and buying behavior (Cant, 2013, p. 149).

Demographic variables include the study of people's vital statistics which includes age, race, sexual category, religious conviction, family unit size, yearly income, LSM, and profession (Cant, 2013, p. 149; Koekemoer, 2014, p. 85). These characteristics are strongly related to customer buying behavior and are predictors of how the target market will respond to a specific marketing mix (Parumasu \& RobertsLombard, 2012, p. 53). With the diverse population 
and cultural groups in South Africa, race is heavily used by organizations as a base for market segmentation (Cant, 2013, p. 157).

Psychographic variables include the attitudes, social class, personality, lifestyle and the opinions of customers (Cant, 2013, p. 161; Koekemoer, 2014, p. 85). While demographic variables allow for information to describe who buys, psychographic information allows us to understand why customers buy (Parumasu \& Roberts-Lombard, 2012, p. 176).

Buying behavior variables include purchase occurrence, purchase readiness, user status and user rate (Cant, 2013, p. 161). In other words, it refers to "the way that people behave when they buy things, such as what they buy, where they buy, when they shop and how much they spend" (Cambridge Dictionary Online, 2016).

Grouping customers based on the above mentioned variables facilitates choosing the most suitable target segments and thereby using marketing efforts more efficiently. The process of deciding which segment(s) to pursue is referred to as target marketing (Cant, 2013, p. 149). Lamb, Hair and McDaniel (2012) defines a target market as the group of consumers in a market that share the same needs and characteristics, for which the business designs and implements a marketing mix with the intention of satisfying their needs and gaining a profit. Therefore, a business will develop a specific marketing mix for their target market in order to meet the needs of this specific group of customers (Cant \& Van Heerden, 2013, p. 98).

The value of target marketing, and by implication customer knowledge, cannot be underestimated, as it holds many advantages for a business. Through focusing on a specific target market, the business can identify opportunities in the market, determine the needs, wants, likes and dislikes of the consumers in the market and develop specific offerings for them (Brookins, 2014). Target marketing also assists the business in building fruitful relationships with the right customers for the business. Understanding the characteristics of one's target market will assist an organization to develop appropriate marketing strategies and messages for their target market (Lake, 2014).

According to Langford and Male (2001), focusing on a specific market segment may provide a company with experience of the conditions of the market which will improve their response to the needs of the market segment. Koekemoer (2014, p. 85) also emphasizes the vital importance for an organization to define its target market, as money is wasted through inappropriate communication. It is important to note that target marketing is not a once off task, but a continuous process, as the environment and its people change constantly and competitors can capitalize on these changes or gaps in the market if a business does not continue to monitor it (Koekemoer, 2014, p. 85).

One of the ways in which SMEs can improve their business performance is by identifying a market segment which the business can focus their efforts on (Humphries, 2012). Cant (2012) reasons that for an SME to be successful, it must focus its efforts on a specific market segment and make use of any relevant tool to differentiate itself from competitors in the market. Chittithaworn, Islam, Keawchana and Yusuf (2011) state that businesses that focus on a specific target group or segment have the potential to become world class businesses.

\section{Aim of the study}

Taking the above mentioned discussion into consideration, the question remains whether SME owners and managers aim their marketing efforts on a specific target market. In addressing the primary objective, the study determines the demographics, psychographics and buying knowledge levels of SME owners and managers, as a specific target market is primarily described in terms of its demographics, psychographics and buying characteristics.

\section{Methodology}

Data collection was done by means of electronically distributing a self-administered questionnaire consisting of quantitative questions to a sample of SME owners operating in the coastal regions of the Western Cape and KwaZulu-Natal who registered their small businesses at an official state institution for SMEs. The sampling methodology utilized was that of non-probability, convenience sampling, which enabled the researcher to collect data quickly and easily. Sufficient number of questionnaires was distributed to achieve a confidence level of $95 \%$ and an error margin of 5\% at 50\% response distribution. A total of 95 usable responses were received which is an error margin of $9.92 \%$. The online Raosoft sample calculator was used to calculate the sample (Raosoft, 2016).

The quantitative data were analyzed using SAS. The data were checked, coded, corrected and descriptive statistics (frequency counts) were used to describe the findings. Varimax rotation was conducted to assess the underlying structure and Cronbach's Alpha measure was performed to determine consistency of the measurement.

The respondent group consisted of $58.62 \%$ owners (45.45\%), managers (18.18\%) and owner manager $(36.36 \%)$. The majority $(58.46 \%)$ of these businesses have been in operation for less than five years, whereas a small portion $(4.46 \%)$ is in existence for more than 25 years. The majority $(58.62 \%)$ of the 
respondents are female and more than half (56.9\%) of the respondents were older than 40 years. Almost two thirds $(62.12 \%)$ of the respondents have a post school qualification ranging from certificates to post graduate degrees. An overview of the main results is provided in the next section.

\section{Results and discussion}

The small business owners were presented with a list containing customer knowledge statements. They were asked to indicate their customer knowledge on a five point scale ranging from strongly disagree to strongly agree. The Table 1 below is indicative of the results obtained for this question. It is clear from the table that the majority of the respondents agree and strongly agree with the statements "I know why my customers buy from me" (73.5\%); "I know what my customers buy from me" (69.7\%); "I know when my customers buy from me" (67.4\%). The majority of the respondents disagree and strongly disagree with these statements "I know how many vehicles my customers have" (68.9\%); "I know if my customers rent or own a house" (64\%); "I know what type of housing my customers occupy" (58.4\%).

Table 1. Distribution of responses on customer knowledge statements

\begin{tabular}{|c|c|c|c|c|c|c|c|}
\hline & & $\begin{array}{l}\text { Strongly } \\
\text { disagree }\end{array}$ & Disagree & Neither & Agree & $\begin{array}{l}\text { Strongly } \\
\text { agree }\end{array}$ & Total \\
\hline 1 & I know what the average age of my customer is. & $\begin{array}{c}5 \\
5.6 \%\end{array}$ & $\begin{array}{c}32 \\
36.0 \%\end{array}$ & $\begin{array}{c}15 \\
16.9 \%\end{array}$ & $\begin{array}{c}30 \\
33.7 \%\end{array}$ & $\begin{array}{c}7 \\
7.9 \%\end{array}$ & 89 \\
\hline 2 & I know the gender profile of my customers. & $\begin{array}{c}3 \\
3.4 \%\end{array}$ & $\begin{array}{c}24 \\
27.0 \%\end{array}$ & $\begin{array}{c}16 \\
18.0 \%\end{array}$ & $\begin{array}{c}39 \\
43.8 \%\end{array}$ & $\begin{array}{c}7 \\
7.9 \% \\
\end{array}$ & 89 \\
\hline 3 & I know the race profile of my customers. & $\begin{array}{c}7 \\
7.9 \%\end{array}$ & $\begin{array}{c}19 \\
21.3 \%\end{array}$ & $\begin{array}{c}18 \\
20.2 \%\end{array}$ & $\begin{array}{c}38 \\
42.7 \%\end{array}$ & $\begin{array}{c}7 \\
7.9 \%\end{array}$ & 89 \\
\hline 4 & I know the marital status of my customers. & $\begin{array}{c}8 \\
9.1 \%\end{array}$ & $\begin{array}{c}34 \\
38.6 \%\end{array}$ & $\begin{array}{c}23 \\
26.1 \%\end{array}$ & $\begin{array}{c}20 \\
22.7 \%\end{array}$ & $\begin{array}{c}3 \\
3.4 \%\end{array}$ & 88 \\
\hline 5 & I know the family size of my customers. & $\begin{array}{c}10 \\
11.2 \%\end{array}$ & $\begin{array}{c}37 \\
41.6 \%\end{array}$ & $\begin{array}{c}28 \\
31.5 \%\end{array}$ & $\begin{array}{c}12 \\
13.5 \%\end{array}$ & $\begin{array}{c}2 \\
2.2 \%\end{array}$ & 89 \\
\hline 6 & I know in which life stage my customers are. & $\begin{array}{c}12 \\
13.5 \%\end{array}$ & $\begin{array}{c}28 \\
31.5 \%\end{array}$ & $\begin{array}{c}19 \\
21.3 \%\end{array}$ & $\begin{array}{c}26 \\
29.2 \%\end{array}$ & $\begin{array}{c}4 \\
4.5 \%\end{array}$ & 89 \\
\hline 7 & I know the religion of my customers. & $\begin{array}{c}13 \\
14.6 \%\end{array}$ & $\begin{array}{c}34 \\
38.2 \%\end{array}$ & $\begin{array}{c}18 \\
20.2 \%\end{array}$ & $\begin{array}{c}21 \\
23.6 \%\end{array}$ & $\begin{array}{c}3 \\
3.4 \%\end{array}$ & 89 \\
\hline 8 & I know my customers' home language. & $\begin{array}{c}9 \\
10.1 \%\end{array}$ & $\begin{array}{c}27 \\
30.3 \%\end{array}$ & $\begin{array}{c}11 \\
12.4 \%\end{array}$ & $\begin{array}{c}34 \\
38.2 \%\end{array}$ & $\begin{array}{c}8 \\
9.0 \%\end{array}$ & 89 \\
\hline 9 & I know what level of education my customer has reached. & $\begin{array}{c}9 \\
10.1 \%\end{array}$ & $\begin{array}{c}37 \\
41.6 \%\end{array}$ & $\begin{array}{c}16 \\
18.0 \%\end{array}$ & $\begin{array}{c}20 \\
22.5 \%\end{array}$ & $\begin{array}{c}7 \\
7.9 \%\end{array}$ & 89 \\
\hline 10 & I know what type of employment my customers are in. & $\begin{array}{c}7 \\
8.0 \%\end{array}$ & $\begin{array}{c}31 \\
35.2 \%\end{array}$ & $\begin{array}{c}15 \\
17.0 \%\end{array}$ & $\begin{array}{c}27 \\
30.7 \%\end{array}$ & $\begin{array}{c}8 \\
9.1 \%\end{array}$ & 88 \\
\hline 11 & I know in which LSM category my customers are. & $\begin{array}{c}6 \\
6.8 \%\end{array}$ & $\begin{array}{c}34 \\
38.6 \%\end{array}$ & $\begin{array}{c}27 \\
30.7 \%\end{array}$ & $\begin{array}{c}16 \\
18.2 \%\end{array}$ & $\begin{array}{c}5 \\
5.7 \%\end{array}$ & 88 \\
\hline 12 & I know what type of housing my customers occupy. & $\begin{array}{c}12 \\
13.5 \%\end{array}$ & $\begin{array}{c}40 \\
44.9 \%\end{array}$ & $\begin{array}{c}22 \\
24.7 \%\end{array}$ & $\begin{array}{c}14 \\
15.7 \%\end{array}$ & $\begin{array}{c}1 \\
1.1 \%\end{array}$ & 89 \\
\hline 13 & I know if my customers rent or own a house. & $\begin{array}{c}14 \\
15.7 \%\end{array}$ & $\begin{array}{c}43 \\
48.3 \%\end{array}$ & $\begin{array}{c}19 \\
21.3 \%\end{array}$ & $\begin{array}{c}11 \\
12.4 \%\end{array}$ & $\begin{array}{c}2 \\
2.2 \%\end{array}$ & 89 \\
\hline 14 & I know how many vehicles my customers have. & $\begin{array}{c}13 \\
14.9 \%\end{array}$ & $\begin{array}{c}47 \\
54.0 \%\end{array}$ & $\begin{array}{c}17 \\
19.5 \%\end{array}$ & $\begin{array}{c}8 \\
9.2 \%\end{array}$ & $\begin{array}{c}2 \\
2.3 \%\end{array}$ & 87 \\
\hline 15 & I know what my customers' income is per month. & $\begin{array}{c}12 \\
13.5 \%\end{array}$ & $\begin{array}{c}35 \\
39.3 \%\end{array}$ & $\begin{array}{c}9 \\
10.1 \%\end{array}$ & $\begin{array}{c}29 \\
32.6 \%\end{array}$ & $\begin{array}{c}4 \\
4.5 \%\end{array}$ & 89 \\
\hline 16 & I know how often my customers' buy from me. & $\begin{array}{c}5 \\
5.7 \%\end{array}$ & $\begin{array}{c}18 \\
20.5 \%\end{array}$ & $\begin{array}{c}9 \\
10.2 \%\end{array}$ & $\begin{array}{c}48 \\
54.5 \%\end{array}$ & $\begin{array}{c}8 \\
9.1 \%\end{array}$ & 88 \\
\hline 17 & I know why my customers buy from me. & $\begin{array}{c}1 \\
1.1 \%\end{array}$ & $\begin{array}{c}13 \\
14.9 \%\end{array}$ & $\begin{array}{c}9 \\
10.3 \%\end{array}$ & $\begin{array}{c}55 \\
63.2 \%\end{array}$ & $\begin{array}{c}9 \\
10.3 \%\end{array}$ & 87 \\
\hline 18 & I know when my customers buy from me. & $\begin{array}{c}2 \\
2.2 \%\end{array}$ & $\begin{array}{c}15 \\
16.9 \%\end{array}$ & $\begin{array}{c}12 \\
13.5 \%\end{array}$ & $\begin{array}{c}46 \\
51.7 \%\end{array}$ & $\begin{array}{c}14 \\
15.7 \%\end{array}$ & 89 \\
\hline 19 & I know how my customers buy from me. & $\begin{array}{c}4 \\
4.5 \%\end{array}$ & $\begin{array}{c}10 \\
11.2 \%\end{array}$ & $\begin{array}{c}11 \\
12.4 \%\end{array}$ & $\begin{array}{c}51 \\
57.3 \%\end{array}$ & $\begin{array}{c}13 \\
14.6 \%\end{array}$ & 89 \\
\hline 20 & I know what my customers buy from me. & $\begin{array}{c}3 \\
3.4 \%\end{array}$ & $\begin{array}{c}11 \\
12.4 \%\end{array}$ & $\begin{array}{c}13 \\
14.6 \%\end{array}$ & $\begin{array}{c}47 \\
52.8 \%\end{array}$ & $\begin{array}{c}15 \\
16.9 \%\end{array}$ & 89 \\
\hline 21 & I know which method my customers use to pay for the product/service I sell. & $\begin{array}{c}3 \\
3.4 \%\end{array}$ & $\begin{array}{c}16 \\
18.2 \%\end{array}$ & $\begin{array}{c}14 \\
15.9 \%\end{array}$ & $\begin{array}{c}43 \\
48.9 \%\end{array}$ & $\begin{array}{c}12 \\
13.6 \%\end{array}$ & 88 \\
\hline 22 & $\begin{array}{l}\text { I know where my customers search for information about my } \\
\text { product/service. }\end{array}$ & $\begin{array}{c}8 \\
9.3 \%\end{array}$ & $\begin{array}{c}18 \\
20.9 \%\end{array}$ & $\begin{array}{c}15 \\
17.4 \%\end{array}$ & $\begin{array}{c}38 \\
44.2 \%\end{array}$ & $\begin{array}{c}7 \\
8.1 \%\end{array}$ & 86 \\
\hline 23 & I know what type of media my customers use. & $\begin{array}{c}5 \\
5.7 \%\end{array}$ & $\begin{array}{c}29 \\
33.0 \%\end{array}$ & $\begin{array}{c}25 \\
28.4 \%\end{array}$ & $\begin{array}{c}20 \\
22.7 \%\end{array}$ & $\begin{array}{c}9 \\
10.2 \%\end{array}$ & 88 \\
\hline 24 & $\begin{array}{l}\text { I know that my customers are active on social media sites such as Twitter } \\
\text { and Facebook. }\end{array}$ & $\begin{array}{c}8 \\
9.1 \%\end{array}$ & $\begin{array}{c}36 \\
40.9 \%\end{array}$ & $\begin{array}{c}8 \\
9.1 \%\end{array}$ & $\begin{array}{c}27 \\
30.7 \%\end{array}$ & $\begin{array}{c}9 \\
10.2 \%\end{array}$ & 88 \\
\hline
\end{tabular}


Table 1 (cont.). Distribution of responses on customer knowledge statements

\begin{tabular}{|c|c|c|c|c|c|c|c|}
\hline & & $\begin{array}{l}\text { Strongly } \\
\text { disagree }\end{array}$ & Disagree & Neither & Agree & $\begin{array}{l}\text { Strongly } \\
\text { agree }\end{array}$ & Total \\
\hline 25 & I know my customers are loyal towards my business. & $\begin{array}{c}8 \\
9.2 \%\end{array}$ & $\begin{array}{c}25 \\
28.7 \%\end{array}$ & $\begin{array}{c}17 \\
19.5 \%\end{array}$ & $\begin{array}{c}28 \\
32.2 \%\end{array}$ & $\begin{array}{c}9 \\
10.3 \%\end{array}$ & 87 \\
\hline 26 & $\begin{array}{l}\text { I know my customers are positive, neutral or negative towards the } \\
\text { product/service I sell. }\end{array}$ & $\begin{array}{c}8 \\
9.1 \%\end{array}$ & $\begin{array}{c}27 \\
30.7 \%\end{array}$ & $\begin{array}{c}21 \\
23.9 \%\end{array}$ & $\begin{array}{c}24 \\
27.3 \%\end{array}$ & $\begin{array}{c}8 \\
9.1 \%\end{array}$ & 88 \\
\hline 27 & I know how often my customers buy the product/service I sell. & $\begin{array}{c}12 \\
13.6 \%\end{array}$ & $\begin{array}{c}27 \\
30.7 \%\end{array}$ & $\begin{array}{c}12 \\
13.6 \% \\
\end{array}$ & $\begin{array}{c}28 \\
31.8 \%\end{array}$ & $\begin{array}{c}9 \\
10.2 \%\end{array}$ & 88 \\
\hline 28 & I know how often my customers use the product/service I sell. & $\begin{array}{c}18 \\
20.7 \%\end{array}$ & $\begin{array}{c}23 \\
26.4 \%\end{array}$ & $\begin{array}{c}9 \\
10.3 \%\end{array}$ & $\begin{array}{c}28 \\
32.2 \%\end{array}$ & $\begin{array}{c}9 \\
10.3 \%\end{array}$ & 87 \\
\hline 29 & I know that my customer's use my product as a necessity. & $\begin{array}{c}15 \\
17.4 \%\end{array}$ & $\begin{array}{c}20 \\
23.3 \%\end{array}$ & $\begin{array}{c}15 \\
17.4 \%\end{array}$ & $\begin{array}{c}28 \\
32.6 \%\end{array}$ & $\begin{array}{c}8 \\
9.3 \%\end{array}$ & 86 \\
\hline 30 & I know that my customers use my product as a 'nice to have'. & $\begin{array}{c}13 \\
14.8 \%\end{array}$ & $\begin{array}{c}32 \\
36.4 \%\end{array}$ & $\begin{array}{c}16 \\
18.2 \%\end{array}$ & $\begin{array}{c}21 \\
23.9 \%\end{array}$ & $\begin{array}{c}6 \\
6.8 \%\end{array}$ & 88 \\
\hline 31 & I know what the interests of my customers are. & $\begin{array}{c}11 \\
12.5 \%\end{array}$ & $\begin{array}{c}25 \\
28.4 \%\end{array}$ & $\begin{array}{c}16 \\
18.2 \%\end{array}$ & $\begin{array}{c}32 \\
36.4 \%\end{array}$ & $\begin{array}{c}4 \\
4.5 \%\end{array}$ & 88 \\
\hline 32 & I know what the opinions of my customers are. & $\begin{array}{c}10 \\
11.5 \%\end{array}$ & $\begin{array}{c}31 \\
35.6 \%\end{array}$ & $\begin{array}{c}13 \\
14.9 \%\end{array}$ & $\begin{array}{c}27 \\
31.0 \%\end{array}$ & $\begin{array}{c}6 \\
6.9 \%\end{array}$ & 87 \\
\hline 33 & I know what the values of my customers are. & $\begin{array}{c}11 \\
12.8 \%\end{array}$ & $\begin{array}{c}37 \\
43.0 \%\end{array}$ & $\begin{array}{c}12 \\
14.0 \%\end{array}$ & $\begin{array}{c}23 \\
26.7 \%\end{array}$ & $\begin{array}{c}3 \\
3.5 \%\end{array}$ & 86 \\
\hline 34 & I know what the lifestyles of my customers are. & $\begin{array}{c}16 \\
18.8 \%\end{array}$ & $\begin{array}{c}32 \\
37.6 \%\end{array}$ & $\begin{array}{c}14 \\
16.5 \%\end{array}$ & $\begin{array}{c}23 \\
27.1 \%\end{array}$ & $\begin{array}{c}0 \\
0.0 \%\end{array}$ & 85 \\
\hline
\end{tabular}

6.1. Construct validity of marketing methods. To examine construct validity of measures adopted in this study, a factor analysis was performed. Maximum Likelihood extraction with varimax rotation was conducted to assess the underlying structure for the thirty four items. Three factors were requested, based on the scree plot, eigen values and \% of variance, as well as the minimum of three items per construct. After rotation, the first factor accounted for $24.62 \%$ of the variance, the second factor accounted for $18.83 \%$, the third factor accounted for $12.80 \%$. The table below displays the items and factor loadings for the rotated factors, with loadings less than 0.40 omitted to improve clarity.

Table 2. Factor loadings for the rotated factors

\begin{tabular}{|c|c|c|c|c|}
\hline & & Factor 1 & Factor 2 & Factor 3 \\
\hline 1 & I know what the average age of my customer is. & 0.12 & 0.69 & 0.29 \\
\hline 2 & I know the gender profile of my customers. & 0.02 & 0.70 & 0.22 \\
\hline 3 & I know the race profile of my customers. & 0.06 & 0.68 & 0.30 \\
\hline 4 & I know the marital status of my customers. & 0.11 & 0.82 & 0.02 \\
\hline 5 & I know the family size of my customers. & 0.17 & 0.80 & 0.08 \\
\hline 6 & I know in which life stage my customers are. & 0.27 & 0.82 & -0.0 \\
\hline 7 & I know the religion of my customers. & 0.21 & 0.79 & 0.07 \\
\hline 8 & I know my customers' home language. & 0.24 & 0.58 & 0.07 \\
\hline 9 & I know what level of education my customer has reached. & 0.31 & 0.60 & 0.11 \\
\hline 10 & I know what type of employment my customers are in. & 0.44 & 0.58 & 0.26 \\
\hline 11 & I know in which LSM category my customers are. & 0.47 & 0.41 & 0.05 \\
\hline 12 & I know what type of housing my customers occupy. & 0.48 & 0.44 & 0.03 \\
\hline 13 & I know if my customers rent or own a house. & 0.38 & 0.32 & -0.0 \\
\hline 14 & I know how many vehicles my customers have. & 0.26 & 0.20 & -0.0 \\
\hline 15 & I know what my customers' income is per month. & 0.17 & 0.38 & 0.07 \\
\hline 16 & I know how often my customers' buy from me. & 0.12 & 0.37 & 0.48 \\
\hline 17 & I know why my customers buy from me. & 0.12 & 0.07 & 0.79 \\
\hline 18 & I know when my customers buy from me. & 0.03 & 0.13 & 0.90 \\
\hline 19 & I know how my customers buy from me. & 0.04 & 0.21 & 0.90 \\
\hline 20 & I know what my customers buy from me. & 0.20 & 0.14 & 0.79 \\
\hline 21 & I know which method my customers use to pay for the product/service I sell. & 0.32 & 0.05 & 0.68 \\
\hline 22 & I know where my customers search for information about my product/service. & 0.52 & 0.16 & 0.32 \\
\hline 23 & I know what type of media my customers use. & 0.64 & 0.24 & 0.17 \\
\hline 24 & I know that my customers are active on social media sites such as Twitter and Facebook. & 0.75 & 0.20 & -0.0 \\
\hline 25 & I know my customers are loyal towards my business. & 0.75 & 0.28 & 0.27 \\
\hline 26 & I know my customers are positive, neutral or negative towards the product/service I sell. & 0.72 & 0.22 & 0.22 \\
\hline
\end{tabular}


Table 2 (cont.). Factor loadings for the rotated factors

\begin{tabular}{|c|c|c|c|c|}
\hline & & Factor 1 & Factor 2 & Factor 3 \\
\hline 27 & I know how often my customers buy the product/service I sell. & 0.75 & 0.27 & 0.29 \\
\hline 28 & I know how often my customers use the product/service I sell. & 0.77 & 0.20 & 0.28 \\
\hline 29 & I know that my customer's use my product as a necessity. & 0.79 & 0.16 & 0.13 \\
\hline 30 & I know that my customers use my product as a 'nice to have'. & 0.71 & 0.18 & 0.00 \\
\hline 31 & I know what the interests of my customers are. & 0.78 & 0.11 & 0.04 \\
\hline 32 & I know what the opinions of my customers are. & 0.80 & 0.02 & 0.09 \\
\hline 33 & I know what the values of my customers are. & 0.84 & 0.10 & 0.06 \\
\hline 34 & I know what the lifestyles of my customers are. & 0.66 & 0.12 & 0.11 \\
\hline & $\%$ of variance explained & 24.62 & 18.83 & 12.80 \\
\hline & $\%$ of cumulative variance explained & 24.62 & 43.54 & 56.25 \\
\hline
\end{tabular}

Note: maximum likelihood extraction was used with varimax rotation and Kaiser normalization, $\mathrm{N}=95$. Factor $1=$ psychographic score; Factor $2=$ demographic score; Factor $3=$ buying score.

It is clear from Table 2 that most factor loadings were 0.4 or above, showing good convergent validity. The constructs are, therefore, uni-dimensional and factorial distinct, and all items used to operationalize a constructs load onto a single factor. Some cross loadings were experienced, as well as a number of items that didn't load anywhere.

6.2. Measures. Reliability is the consistency of the measurement, or the degree to which an instrument measures the same way each time it is used under the same condition with the same subjects. A Cronbach's Alpha value above 0.8 have a good reliability, a value between 0.6 and 0.8 have an acceptable reliability and a value below 0.6 have an unacceptable reliability.

The Cronbach's Alpha for the three sub-constructs all yielded high Cronbach's Alpha values $(>=0.80)$ which is considered very good. The table below represents the Cronbach's Alpha values of each of the four sub-constructs. Hence, the results demonstrate that the questionnaire is a reliable measurement instrument.

Table 3. Cronbach's alpha values

\begin{tabular}{|l|c|c|}
\hline \multicolumn{1}{|c|}{ Construct/ Scale } & Items & Cronbach's Alpha \\
\hline Psychographic score & $22-34$ & 0.95 \\
\hline Demographic score & $1-10$ & 0.92 \\
\hline Buying score & $16-21$ & 0.90 \\
\hline
\end{tabular}

The score for each of the constructs biographic, buying and lifestyle is represented by a single value by calculating the mean of the applicable items relating to the construct. The constructs average on a 5 point scale as follows: buying $3.59(s=0.85)$; demographic $2.9(s=0.85)$ and psychographic 2.89 $(s=0.93)$ implying that SME owners and managers have a better knowledge of customer buying and buying patterns than customer demographic and psychographic aspects.

6.3. Target market. The respondents were asked whether they have a specific target market. Figure 1 below is indicative of the results obtained for this question. It is clear from the figure that the majority (90\%) of the respondents have a specific target market.

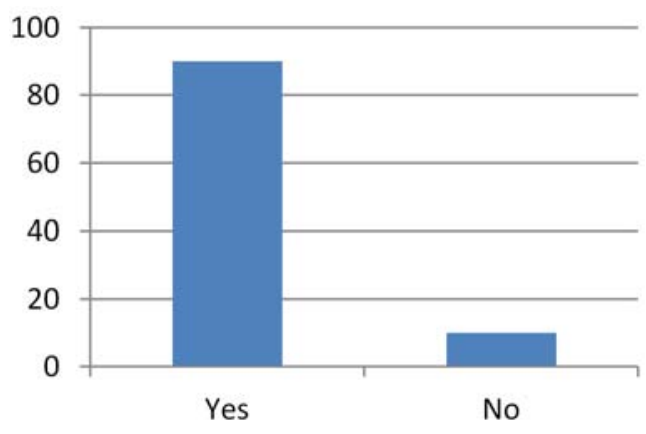

Fig. 1. Target a specific market

An independent T-test showed no significant difference $(t(79)=-1.17 ; p=0.25)$ between the construct demographics and SMEs that have a specific target market $(M=2.99 ; s=0.80)$ and the SMEs without a specific target market $(M=2.63 ; s=1.09)$. No significant difference $(t(79)=-1.51 ; p=0.13)$ between the construct buying and SMEs that have a specific target market $(M=3.66 ; s=0.79)$ and the SMEs without a specific target market $(M=3.2 ; s=$ 1.06) was revealed by the independent T-test. An independent $\mathrm{T}$-test showed no significant difference $(t(78)=-049 ; p=0.62)$ between the construct psychographic and SMEs that have a specific target market $(M=2.94 ; s=0.93)$ and the SMEs without a specific target market $(M=2.77 ; s=0.98)$.

\section{Discussion}

An essential component to the success of an SME is its business plan, which includes background information on the firm and its team, as well as goals and objective that will drive the firm into the future and towards success. An important component of the business plan is the description of the firm's target market. A target market is a group of customers that a firm will be targeting directly with its products and/or services. A target market is defined in terms of 
geographic, demographic and psychographic variables. Geographic variables refer to the territories or location where the firm will operate in; demographic variables refer to personal statistics such as income, gender, education, and family size, which are used to formulate the target customer profile; psychographic variables refer to the lifestyle, interests, opinions and activities of the target market.

The objective of the study is to explore whether SMEs have a target market and their knowledge of their target market. It is clear from the research that the majority (90\%) have a specific target market. A factor analysis revealed three constructs: buying, demographic and psychographics. An independent Ttest showed that there is no significant difference for the three constructs between the respondents who indicated that they have a target market and the respondents who don't have a target market. The research revealed that SMEs have limited knowledge of demographic and psychographic aspects regarding their target market and their target consumer group.
In contrast, they have above average knowledge of the buying patterns of their target market. SMEs are in position to plan their merchandising and to certain extent manage their inventory. By knowing the target market and with effective communication, SMEs can improve on their merchandise planning and product assortments and offerings to the target market. An improved inventory turnover will improve SME sustainability and profitability.

\section{Conclusion and recommendations}

It is clear from the research that SME owners and managers lack knowledge in target marketing. Although they indicate that they market to a specific target market, they have below average knowledge of their target market that gives life to the idea that they are aiming for the moon and hope to land among the stars. It is, therefore, recommended that SME owners and managers familiarize themselves and apply marketing principles, as it might increase growth and profitability of the firm.

\section{References}

1. Abor, J. \& Quartey, P. (2010). Issues in SME development in Ghana and South Africa, International research Journal of Finance and Economics, 39, pp. 218-226. Available at: http://www.smmeresearch.co.za/userfiles/file/Issues $\% 20$ in $\% 20$ SME\%20development\%20in\%20Ghana\%20and\%20SA.pdf.

2. Anon. (2016). What is customer knowledge? Available at: http://www.dobney.com/Knowledge/ck_definition.htm.

3. Bresciani, S. \& Eppler, M.J. (2010). Brand new ventures? Insights on start-ups' branding practices, Journal of Product \& Brand Management, 19 (5), pp. 356-366.

4. Brink, A. Cant, M.C. \& Ligthelm, A. (2003). Problems experienced by small business in South Africa. Paper for the Small Enterprise Associaition of Australa and New Zealand $16^{\text {th }}$ Annual Conference. Ballarat, 28 Sept-1 Oct, 2003.

5. Brookins, M. (2014). Reasons for having a target market strategy. Available at: http://smallbusiness.chron.com/reasons-having-target-market-strategy-3251.html.

6. Business Dictionary. (2016). Customer Knowledge Management. Available at: http://www.businessdictionary.com/definition/customerknowledgemanagement.html.

7. Caan, J. (2013). SME's are the backbone of the economy. Available at: http://money.uk.msn.com/makemoney/smes-are-the-backbone-of-the-economy.

8. Cambridge Dictionaries online. (2016). Buying Behavior. Available at: http://dictionary.cambridge.org/dictionary/english/buying-behavior.

9. Cant, M.C. (2012). Challenges Faced By SME's In South Africa: Are Marketing Skills Needed? International business and economic research journal, 11 (10), pp. 1107-1116.

10. Cant, M.C. (2013). Essential of marketing. $4^{\text {th }}$ ed. Cape Town: Juta.

11. Cant, M.C. \& Van Heerden. (2013). Marketing Management: A South African Perspective. Claremont: Juta \& Company.

12. Cant, M.C. \& Wiid, J.A. (2013). Establishing the challenges affecting South African SME's, International Business and Economics Research Journal, 12 (6), pp. 707-716.

13. Carvalho, R.P.G. (2007). The role of branding in SME start-ups. Unpublished master thesis. University of Pretoria. Available at: http://upetd.up.ac.za/thesis/available/etd-03202010-181051/unrestricted/dissertation.pdf.

14. Chimucheka, T. (2013). Overview and performance of the SMMEs sector in South Africa, Mediteranean Journal of Social Sciences, 4 (14), pp. 783-795.

15. Chittithaworn, C., Islam, A., Keawchana, T. \& Yusuf, D.H.M. (2011). Factors Affecting Business Success of Small \& Medium Enterprises (SMEs) in Thailand, Asian Social Science, 7 (5), pp. 180-190.

16. Etuk, R.F., Etuk, G.R. \& Baghebo, M. (2014). Small And Medium Scale Enterprises (SMEs) And Nigeria's Economic Development, Mediterranean Journal of Social Science, 5 (7), pp. 656-662. Available at: http://www.mcser.org/journal/index.php/mjss/article/view/2526/2494.

17. European commission. (2003). Commission Recommendation of 6 May 2003 concerning the definition of micro, small and medium-sized enterprises, Official Journal of European Union, pp. 36-41. Available at: http://eurlex.europa.eu/LexUriServ/LexUriServ.do?-uri=OJ:L:2003:124:0036:0041:EN:PDF.

18. European Commission. (2005). The new SME definition: User guide and model declaration. Available at: 
http://ec.europa.eu/enterprise/policies/sme/files/sme_definition-/sme_user_guide_en.pdf.

19. Ghandi, E.C. \& Amissah, G. (2014). Financing Options for small and medium enterprises (SME's) in Nigeria, European Scientific Journal, 10 (1), pp. 327-340.

20. Government Gazette of the Republic of South Africa. (2003). National Small Business Amendment Act. Available at: http://www.gov.za/documents/download.php?f=68002.

21. Hove, P. \& Mashocha, R. (2014). Interaction of technological marketing and Porter's five competitive forces on SME competitiveness in South Africa, Mediterranean Journal of Social Sciences, 5 (4), pp. 254-262.

22. Humphries, L. (2012). How to determine your business' target market. Aviable at: http://www.investopedia.com/financial-edge/1112/how-to-determine-your-business-target-market.aspx.

23. Krake, F.B.G.J.M. (2005). Successful brand management in SMEs: a new theory and practical hints, Journal of Product \& Brand Management, 14 (4), pp. 228-238.

24. Koekemoer, L. (ed). (2014). Marketing Communication: An Integrated Approach. Cape Town: Juta.

25. Ladzani, W. \& Mbonyane, W. (2011). Fcators that hinder the growth of small businesses in South African Townships, European business review, 23 (6), pp. 550-560.

26. Lake, L. (2014). Marketing basics for small business. Available at: http://marketing.about.com/od/marketingbasics/a/smmktgbasics.htm.

27. Lamb, C., Hair, J. \& McDaniel, C. (2012). Essentials of marketing. $7^{\text {nd }}$ ed. Ohio: South-Western Cengage.

28. Langford, D. \& Male, S. (2001). Strategic Management in Construction. Oxford: Blackwell Science.

29. Modimogale, L. (2008). ICT and SMEs' competitiveness in South Africa: How SMEs could use ICT to become competitive in South Africa. Unpublished master thesis. University of Pretoria. Available at: http://upetd.up.ac.za/thesis/available/etd-08272008-111005/unrestricted/dissertation.pdf.

30. Mohammadhossein, N., Zakaria, N.H., Rafsanjani, H.A. \& Asadi, S. (2013). The relationship of knowledge management and market segmentation on CRM, Journal of Basic Applied Scientific Research, 3 (4), pp. 615-626.

31. Mpofu, T. \& Chingwede, S. (2013). Factors influencing marketing planning and implementation in Zimbabwean SME's, International Journal of Science: Basic and Applied research, 12 (1), pp. 82-92. Available at: http://gssrr.org/index.php?journal=JournalOfBasicAndApplied-\&page=article\&op=view\&path $\% 5 \mathrm{~B} \% 5 \mathrm{D}=1128$.

32. Notcutt, K. \& Habberton, G. (2013). Unlocking the growth of SMEs and social businesses in South Africa. Available at: http://impacttrust.org.za/blog/unlocking-sme-and-social-business-growth-in-south-africa/.

33. Olawale, F. \& Garwe, D. (2010). Obstacles to the growth of new SMEs in South Africa: A principal component analysis approach, African Journal Business Management, 4 (5), pp. 729-738. Available at: http://www.academicjournals.org/article/article1380715803-Olawale\%20and\%20Garwe.pdf.

34. Parumasur, S.B. \& Roberts-Lombard, M. (2012). Consumer behavior. $2^{\text {nd }}$ ed. Cape Town: Juta.

35. Raosoft. (n.d.). Raosoft Sample Calculator. Available at: http://www.raosoft.com/samplesize.html.

36. Selvaggio, L. (2014). Target Market Analysis: Why It's Important and How to Apply it. Available at: https://blog.udemy.com/target-market-analysis/.

37. Tang, Y., Wang, P. \& Zhang, Y. (2007). Marketing and business performance of construction SMEs in China, Journal of Business \& Industrial Marketing, 22 (2), pp. 118-125.

38. Van Scheers, L. (2011). SMEs' marketing skills challenges in South Africa, African Journal of Business Management, 5 (13), pp. 5048-5056. 